\title{
On the applicability of the pipe model theory on the chestnut tree (Castanea sativa Mill.)
}

\author{
Eric Gehring • Gianni Boris Pezzatti • \\ Patrik Krebs $\cdot$ Stefano Mazzoleni $\cdot$ Marco Conedera
}

Received: 16 January 2014/Revised: 12 August 2014/Accepted: 5 September 2014/Published online: 28 January 2015

(c) Springer-Verlag Berlin Heidelberg 2015

\begin{abstract}
Key message Leaf to sapwood area ratio in Castanea sativa is constant within a branch, but decreases with branch height. We propose a modeling approach to mitigate this effect.

Abstract The pipe model theory postulates the constancy of the relationship between leaf to sapwood area among single parts and for a whole tree. By analyzing 218 branches belonging to 67 different chestnut trees (Castanea sativa Mill.), we tested the correctness of this postulate at three different levels: intra-branch, among different branch types (structural crown branches vs. epicormic branches), and within structural branches of the same trees. Results confirm the constancy of the leaf to sapwood area ratio $\left(A_{L}: A_{S}\right.$ ratio) at the intra-branch level, but show variability among branches within a tree. The $A_{L}: A_{S}$ ratio of crown branches declines with height. Furthermore, epicormic branches display enhanced sturdiness with respect to crown branches. A generalized linear mixed modeling approach was used to explain the intra-tree $A_{L}: A_{S}$ ratio variability of structural crown branches. The main explanatory variable on the $A_{L}: A_{S}$ ratio within a chestnut tree was found to be the height of the branch insertion. To neutralize this effect
\end{abstract}

Communicated by Y. Sano.

E. Gehring $(\bowtie) \cdot$ G. B. Pezzatti · P. Krebs · M. Conedera Insubric Ecosystems Research Group, WSL Swiss Federal Research Institute, Via Belsoggiorno 22, 6500 Bellinzona, Switzerland

e-mail: eric.gehring@wsl.ch

\section{S. Mazzoleni}

Dip. di Arboricoltura, Botanica e Patologia Vegetale, University of Naples Federico II, via Universit 100, 80055 Portici, Naples, Italy when comparing the $A_{L}: A_{S}$ ratio among different trees for general environmental and physiological studies, we propose the concept of the $A_{L}: A_{S g r o u n d}$ consisting of the $A_{L}: A_{S}$ ratio of a hypothetical branch at ground level.

Keywords Leaf to sapwood area ratio . Biomass allocation - Structural crown branches . Branch height $\cdot$ European chestnut

\section{Introduction}

The analysis of tree structures represents a key factor for understanding physiological acclimation mechanisms of trees subjected to different ecological conditions and environmental stresses (Martin-Stpaul et al. 2013; Bleby et al. 2012).

Since the first attempts to apply plant architecture to tree ecology and physiology studies in the early decades of the 20th century (e.g., Arber 1928, 1950), different tree architectural empirical models and crown structure adaptation patterns have been defined (Hallé and Oldeman 1970; Hallé et al. 1978; Ito et al. 1995; Ishii et al. 2007; Otoda and Ishii 2008). The hydraulic architecture approach (Zimmermann 1983), in particular, attempts to link plant architecture to physiological processes by considering the tree as an assembly of pipes where water flow is driven and regulated by physical processes (Tyree and Ewers 1991) based on the Ohm's electrical principles (i.e., resistance, capacitance, water potential, and flow-Cruiziat et al. 2002). In tree architectural terms, such approaches lead to the search for allometric relationships between roots, stem, and leaves describing the functional relationship between the conducting pipes (vascular system) and the photosynthetic biomass (McDowell et al. 2002; Wright et al. 2006; 
Gould and Harrington 2008). An example is the Huber value (HV), which is defined as the sapwood cross-section (or the branch cross-section) divided by the leaf area (or sometimes the leaf dry weight) distal to the branch (Huber 1928; Zimmermann 1983). Shinozaki et al. (1964a, b) extended this concept to tree structure assuming that the xylem conductive tissue of woody plants corresponds to an assemblage of pipe units supporting a correspondent sector of leaves (pipe model) what results in a constant ratio between leaf area $\left(\mathrm{A}_{\mathrm{L}}\right)$ and sapwood area $\left(\mathrm{A}_{\mathrm{S}}\right)$ within a single branch or tree.

Many studies and experimental results support the pipe model hypothesis (e.g., Bartelink 1997; Infante et al. 2001; Sone et al. 2009), reporting direct evidence for the leaf to sapwood area relationship (e.g., Kaufmann and Troendle 1981; Gould and Harrington 2008; Mazzoleni and Schirone 1990) or applying the pipe model approach to describe water conduction and storage processes (Mäkelä 1986; Ewers and Zimmermann 1984a, b; Yamamoto and Kobayashi 1993), canopy conductance principles (Novick et al. 2009), tree resource allocation and resulting branching structure (Chiba 1990, 1991, 1998), aboveground forest productivity (Magnani et al. 2000), and indirect leaf area, leaf mass, and resource allocation estimations (Snell and Brown 1978). On the other hand, a number of studies report inconsistencies in the $A_{L}: A_{S}$ relationship that tends to taper in a non-linear way along the trunk of a tree (Dean and Long 1986; White et al. 1998), to decrease (e.g., Mencuccini and Grace 1996; McDowell et al. 2002; Delzon et al. 2004) or even, in particular cases, to increase (Phillips et al. 2003a) with tree size or age. Moreover, $\mathrm{A}_{\mathrm{L}}: \mathrm{A}_{\mathrm{S}}$ relationship varies depending on silvicultural practices (Aussenac and Granier 1988; Pothier and Margolis 1991) or site conditions (e.g., water and nutrients availability, Mazzoleni and Schirone 1990; Mencuccini 2003; Gotsch et al. 2010). Furthermore, the pipe model does not take some important physiological aspects into consideration, such as the different length of the pathways that water has to go through from soil to leaves (Tyree and Ewers 1991) or the branch autonomy paradigm that states that photosynthates produced in a branch are rarely transported into neighboring branches (Sprugel et al. 1991; Miyazaki et al. 2002; Hasegawa et al. 2003). Finally, aging or environmental disturbances may modify the inherited structural model of a tree inducing the formation of different branch types such as epicormic branches (trunk suckers or reiterations sensu Hallé et al. 1978) which may display different hydraulic characteristics and different $A_{L}: A_{S}$ ratios with respect to normal structural branches (Ishii et al. 2007; Otoda and Ishii 2008).

In summary, the pipe model approach has the potential to be a very useful tool for environmental research, but only if applied considering species-specific characteristics and avoiding misinterpretations (Brix and Mitchell 1983; Mencuccini and Grace 1994; Cruiziat et al. 2002). To contribute to solve some of the issues raised by contrasting literature and to verify the suitability of the pipe model approach for environmental studies referring to tree species, we set up a study design on Castanea sativa in southern Switzerland. The overall aim of this research is thus to verify the consistency and constancy of the pipe model within branches and trees, using the European chestnut (Castanea sativa Mill.) as a case species. In particular, we examine what the model postulates at three different levels:

A. Within single branches;

B. Between different branch types, specifically structural crown branches versus epicormic branches (reiterations sensu Hallé et al. 1978);

C. Within a tree, including the analysis of factors that influence variations in the $A_{L}: A_{S}$ ratio.

We finally discuss the results in light of practical applications in environmental studies.

\section{Materials and methods}

\section{Study site}

The study was conducted in the chestnut forests of the Insubric region of canton Ticino, Switzerland (Fig. 1). The climate is moist (mean annual precipitation: $1,876 \mathrm{~mm}$ ) and warm (mean annual temperature $11.3{ }^{\circ} \mathrm{C}$; climatic normals 1981-2010 of Locarno-Monti, MeteoSwiss). Soils are generally classified as haplic podzol (cryptopodzol) on crystalline bedrock. The chestnut was introduced by the Romans nearly 2,000 years ago (Tinner et al. 1999) and became the dominant tree species on acid soils in the socalled chestnut belt that stretches from 200 to $700-1000 \mathrm{~m}$ a.s.l. depending on the aspect. The chestnut tree is nowadays still present on different microtopographic conditions, from ridge to furrow and from tor to extreme depression.

\section{Sampling design}

A total of 218 branches belonging to 67 wild (not grafted for fruit production) trees were sampled at different tree heights and orientations in sites located at different elevations, aspects, slopes, and microtopographic conditions.

Collected branches were classified into two different types: normal (structural) crown branches and epicormic branches. Epicormic branching in chestnut is mainly due to environmental disturbance (fall or death of branches or crown parts due to heavy snow, fire, and insect defoliation) or environmental stress (e.g., drought-induced crown die 


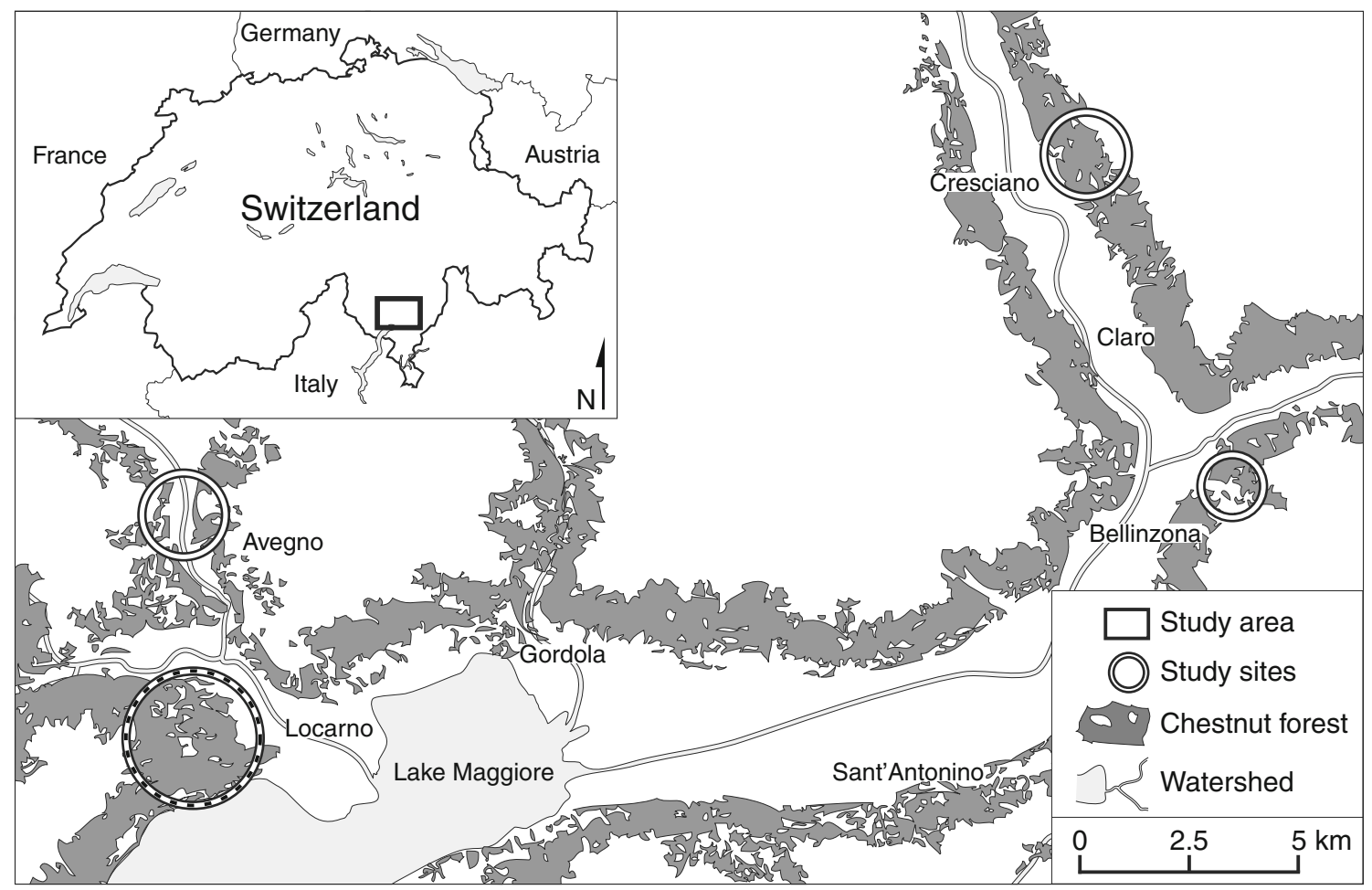

Fig. 1 Study area and detailed location of the study sites (dashed circle representing the "training dataset"). Subfigure in the top-left corner shows the location of the study area (small bold rectangle) in the whole Switzerland

back). Considering mature chestnut trees that already developed rough bark, epicormic branches are distinguishable from crown branches because they arise from an adventitious or dormant bud, usually have smooth bark and are often located close to a broken or dead branch (Fig. 2).

The sampled material was then used differently according to the specific questions to be answered (Table 1):

A. Constancy of the $A_{L}: A_{S}$ ratio within the single branch: whole dataset (218 branches from 67 trees).

B. Consistency of the $A_{L}: A_{S}$ ratio between structural crown branches and epicormic branches: 22 crown branches belonging to 14 trees and 21 epicormic branches belonging to 14 trees collected at similar heights on trees growing in similar site conditions (ridges).

C. Analysis of factors influencing variations in the $A_{L}: A_{S}$ ratio of structural crown branches within a tree. Two sub-samples: a training dataset with 93 branches collected at different heights and orientation from 11 different trees growing in similar site conditions (on average 8.45 branches per tree with a minimum and a maximum number of 4 and 12, respectively); a validation dataset with 65 structural crown branches from 32 trees (on average two branches at different heights and orientation per tree).

\section{Data collection and processing}

Branches were collected during two sampling periods: from June 7th to August 13th, 2009 and from June 16th to July 22nd, 2010. Since no interannual variation in the $\mathrm{A}_{\mathrm{L}}: \mathrm{A}_{\mathrm{S}}$ ratio could be found $(U=678, p>0.05$, nonparametric Mann-Whitney $U$ test) samples were treated as a single dataset. When collecting the branches, we made sure that leaves were fully developed and did not display damage due to climate, parasites, and phytophagous insects. Using tree-climbing techniques, branches were cut, carefully lowered to the ground with a rope, and directly characterized by a number of descriptors (Table 2).

Branches were further processed on the same day to preserve the original form and color of the leaves. Processing consisted of dividing the collected branch into up to ten sections. The position of a section in the branch was carefully noted to enable the reconstruction of the branch structure for the calculation of the leaf area $\left(A_{L}\right)$ of each possible combination of sections (Fig. 3). For each branch section, minimum and maximum cross-section diameters were measured with a caliper, on the smoothest bark $1-3 \mathrm{~cm}$ basal to the branching. The sapwood area $\left(\mathrm{A}_{\mathrm{S}}\right)$ was calculated from the 2 diameters using the ellipse formula, assuming that for small branches (diameters ranging from 
Fig. 2 Examples of a crown branch (a) and an epicormic branch (b) in chestnut tree
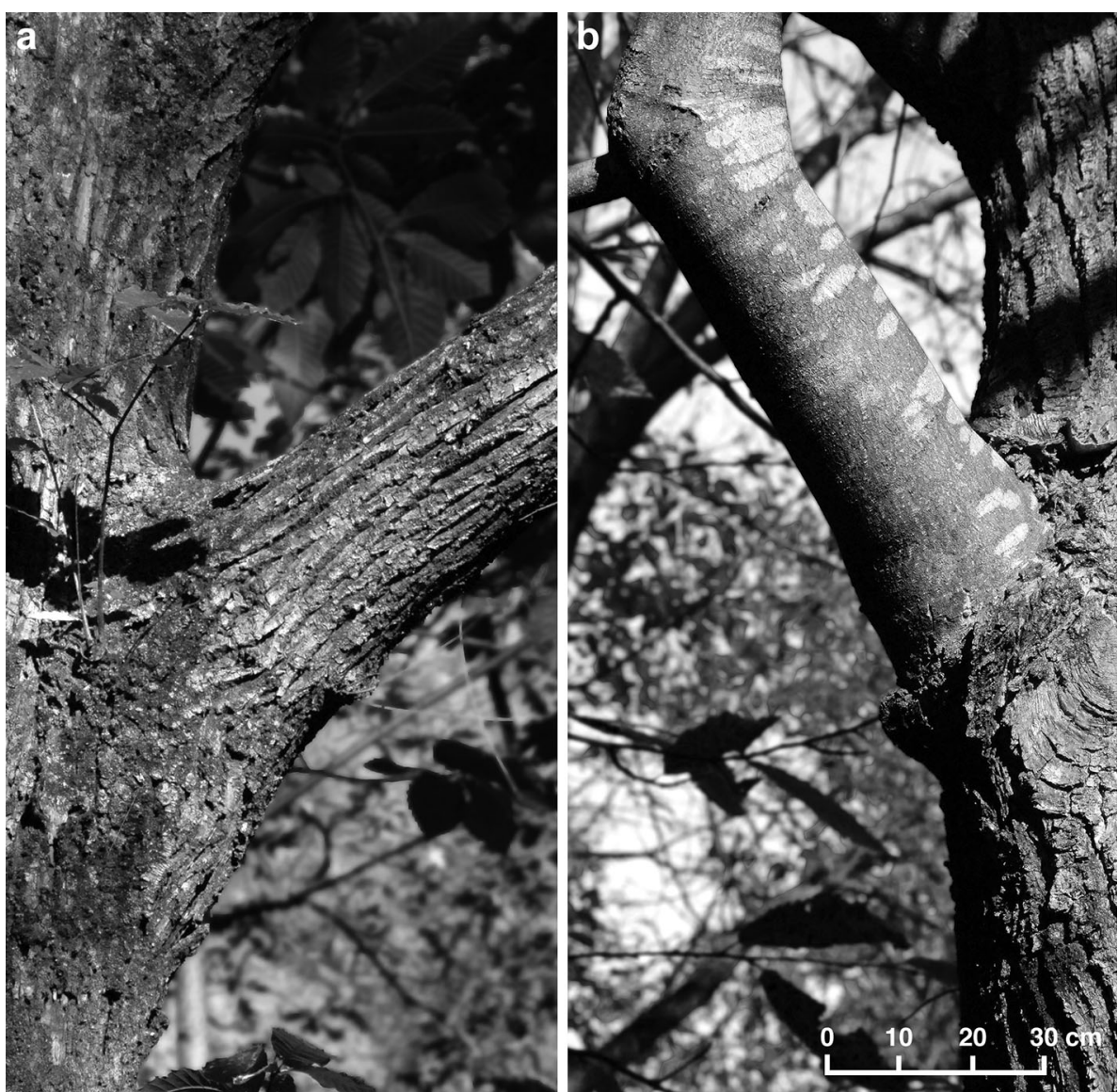

0.7 to $3.8 \mathrm{~cm}$ ) the whole section displays active conductive tissue without any heartwood (Berthier et al. 2001; Gould and Harrington 2008).

All leaves were then detached and digitalized with a scanner (Xerox 9001 machine: resolution 200 dpi, contrast +1 , colored photo quality) to be analyzed with the image processing program Image Pro plus 6.0 (IPP). IPP is able to recognize, count, and measure the area of specific objects (in our case, the leaves on a white background) according to a specific color range.

All measured parameters (see Table 2 for the definitions) were stored in a relational database (PostgreSQL; http://www.postgresql.org) and ad hoc pgSql functions were developed to compute and summarize data according to the hierarchical structure.

Data analysis

To test question A, we first plotted the cumulative leaf area against the correspondent sapwood area for every section and branch to visually evaluate the expected linearity of the relationships. To statistically test the linearity avoiding the use of cumulative leaf area data, we used the terminal sections and a subset of independent data obtained by relating for each branch section the net leaf area to the net sapwood area, both resulting from the subtraction of the areas of the children sections. We finally fitted a linear model without intercept and we used ANOVA tests to verify the similarity among independent and cumulated data.

To answer question $\mathrm{B}$, we performed a univariate comparative analysis on the $A_{L}: A_{S}$ ratio (calculated with the maximum $\mathrm{A}_{\mathrm{L}}$ and $\mathrm{A}_{\mathrm{S}}$ values for every branch) distribution between crown and epicormic branches using the Mann-Whitney $U$ tests (Wilcoxon rank-sum test).

To answer question $\mathrm{C}$ (analysis of factors influencing variations in the $A_{L}: A_{S}$ ratio of branches within a tree), we used a mixed modeling approach (Zuur et al. 2009) to handle the lack of independence of our data within each tree and site. The response variable was the ratio between the maximum value of $A_{L}$ and $A_{S}$ for each branch and the random effects were the sites and the trees (Table 2). In case of highly correlated explanatory variables (Pearson $\mathrm{R} \geq 0.5$; Table 2), the selective criterion was to retain for the analysis only the easiest one to be collected in the field in view of applying the approach for other studies. The best random configuration was determined according to Zuur et al. (2009) and using the R package 


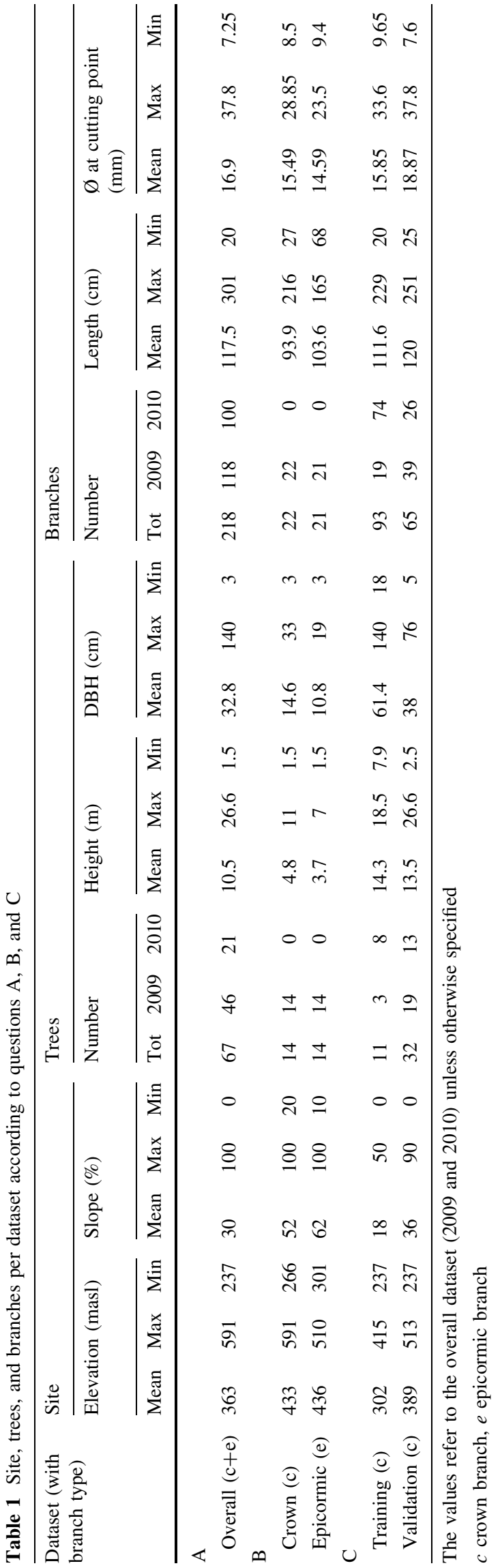

glmulti, we evaluated all possible combinations of explanatory variables (no interactions or polynomial terms have been considered). Using the maximum likelihood estimation (ML), we ranked the models on the basis of the AICc coefficient (Akaike information criterion with a second order correction for small sample size) calculated. To estimate the goodness-of-fit for our models, we used the Cox-R2 (Nagelkerke 1991) and the XuR2 (Xu 2003).

The estimates of the selected model were recalculated using restricted maximum likelihood estimation (REML). To check the normal distribution and evaluate the $p$ values of the recalculated estimates, we used the Markov Chain Monte Carlo (MCMC) to generate a sample of posterior density distribution of the fixed effect parameters using the cran-R-package language.

Finally, the estimates were tested on an independent validation dataset ( 32 trees, with 2 branches each at different heights).

All the analyses were performed using the $\mathrm{R}$ statistical package version 2.14.0 (R Development Core Team 2011).

\section{Results}

\section{Branch level and type}

The relationship between leaf area and sapwood area of consecutive sections of a branch highlights the linear disposition of the cumulative $A_{L}: A_{S}$ ratios within a branch (Fig. 4). The ANOVA tests revealed that only $2.7 \%$ of the regressions based on independent branch sections were statistically different $(p<0.01)$ from those on the cumulated (dependent) data reported in Fig.4, confirming the constancy (linearity) of the $A_{L}: A_{S}$ ratios within a branch. Moreover, the $R^{2}$ of the of the independent $\mathrm{A}_{\mathrm{L}}: \mathrm{A}_{\mathrm{S}}$ ratios was higher than 0.91 in $75 \%$ of the cases and always higher than 0.94 for the cumulated data, confirming the strength of the correlations between the two variables and the constancy (linearity) of the $A_{L}: A_{S}$ ratios within a branch.

Generally, differences in the $A_{L}: A_{S}$ ratio between single branch sections and the whole branch were less than $15.6 \%$ in half of the 1,487 sections analyzed and increased to $29.8 \%$ when $75 \%$ and until $63.7 \%$ when $100 \%$ of the sections were considered. These differences follow a decreasing trend for sections of higher branching order and/or dimension (Fig. 5) reaching differences of only $10.2 \%$ on median for branch diameter between 21 and $28 \mathrm{~mm}$.

Based on these results, we considered for the following questions ( $\mathrm{B}$ and $\mathrm{C}$ ) only the ratio of the maximum value of $A_{L}$ and their $A_{S}$ for each branch, solving so the problem of the non-independent data within the branches. 
Table 2 Branch parameters considered

\begin{tabular}{|c|c|c|c|}
\hline Parameter & Unit & Model $^{\mathrm{a}}$ & Definitions \\
\hline Branch height at cutting point & $\mathrm{m}$ & $\mathrm{x}$ & Distance from ground level \\
\hline $\begin{array}{l}\text { Branch height at main trunk } \\
\text { insertion }\end{array}$ & $\mathrm{m}$ & $(\mathrm{x})$ & Distance from ground level \\
\hline $\begin{array}{l}\text { Branch diameter at main trunk } \\
\text { insertion }\end{array}$ & $\mathrm{cm}$ & $(\mathrm{x})$ & Branch circumference/ $\pi$ \\
\hline Sapwood area & $\mathrm{cm}^{2}$ & $\mathrm{x}$ & Area of ellipse with minimum and maximum branch diameters \\
\hline Total length from main trunk & $\mathrm{cm}$ & $(\mathrm{x})$ & Distance from branch tip to branch insertion to the main trunk \\
\hline Branch length & $\mathrm{cm}$ & $\mathrm{x}$ & Distance from branch tip to cutting point \\
\hline $\begin{array}{l}\text { Structural order from main trunk } \\
\text { to the branch end }\end{array}$ & & $(\mathrm{x})$ & $\begin{array}{l}\text { Number of branching from branch tip to branch insertion to the main trunk (for details see } \\
\text { Fig. 3) }\end{array}$ \\
\hline Branch structural order & & $\mathrm{x}$ & Number of branching from branch tip to cutting point (for details see Fig. 3) \\
\hline Branch age & $\mathrm{y}$ & $\mathrm{x}$ & Number of annual rings at cutting point \\
\hline Branch angle & & $\mathrm{x}$ & $\begin{array}{l}\text { Branch angle at main trunk on a vertical plane (arc-sine(("Branch height at cutting } \\
\text { point" - "Branch height at main trunk insertion")/“Total length from main } \\
\text { trunk") } \times 180 / \pi)\end{array}$ \\
\hline Branch orientation & $0-2$ & $\mathrm{x}$ & $\begin{array}{l}\text { According to cardinal points and transformed following Beers et al. }(1966): \sin (\mathrm{A}+45)+1 . \\
\mathrm{A}=\text { branch azimuth. } 0=\text { southwest facing (more xeric) } ; 2=\text { northeast facing (more } \\
\text { mesic) }\end{array}$ \\
\hline Presence/absence of blight & $0 / 1$ & $\mathrm{x}$ & Presence/absence of Cryphonectria parasitica from branch tip to cutting point \\
\hline Number of cupulae & & $\mathrm{x}$ & Total number of cupulae from branch tip to cutting point \\
\hline Number of flowers & & $\mathrm{x}$ & Total number of male flowers from branch tip to cutting point \\
\hline Minimum diameter & $\mathrm{mm}$ & & Smallest branch diameter at $1-3 \mathrm{~cm}$ basal distance to its branching \\
\hline Maximum diameter & $\mathrm{mm}$ & & Larger branch diameter at $1-3 \mathrm{~cm}$ basal distance to its branching \\
\hline Number of leaves & & $(\mathrm{x})$ & Counts of leaves from branch tip to cutting point \\
\hline Leaf area ${ }^{\mathrm{b}}$ & $\mathrm{m}^{2}$ & $\mathrm{x}$ & $\begin{array}{l}\text { Total number of pixels from the digitalized leaves } \times 1.6129 \times 10^{-8} \text { (conversion for pixels } \\
\text { to } \mathrm{m}^{2} \text { at a resolution of } 200 \text { dots per in.) }\end{array}$ \\
\hline Leaf color ratio (Red/Green) & & $\mathrm{x}$ & Ratio between red/green values of the digitalized leaves \\
\hline
\end{tabular}

a Tested as explaining variable in the intra-tree model (x). Brackets indicate that the variable was excluded due to collinearity with other variables (Pearson $\mathrm{R}>0.5$ )

b Measured with "Image Pro plus 6.0" from the digitalized images

Epicormic branches displayed significantly greater $\mathrm{A}_{\mathrm{L}}: \mathrm{A}_{\mathrm{S}}$ ratios with respect to structural crown branches (Fig. 6; $p<0.001$, non-parametric Mann-Whitney $U$ test) sampled at similar height (non-parametric Wilcoxon test with $p=0.07$ ) and in similar site conditions.

Finally, the $A_{L}: A_{S}$ ratio for all 218 branches under consideration ranged by a factor of 11.5 from a minimum value of 0.12 to a maximum of 1.40 (data not shown).

\section{Tree level}

The best random configuration factor determined for the mixed modeling approach was an intercept random model. The best model in terms of AICc, likelihood, and explained variance among the 2,048 generated, included branch height as the main explanatory variable, branch structural order, and branch orientation (Table 3) as explanatory variables. The $A_{L}: A_{S}$ ratio was found to be negatively correlated with the height of the cutting point (Fig. 7) and the branch structural order, whereas the correlation with branch orientation was positive, meaning that the $A_{L}: A_{S}$ ratio tends to be higher in North East oriented branches. The estimated $p$ values of the fixed effects were significant, except for the branch structural order, which had, in addition, the HPD interval crossing 0 (Table 4), which implies that this factor is unlikely to be significant.

Interestingly, considering the subsequent models, the best one with only two explanatory variables did not perform significantly worse ( $p$ value $=0.06$ ), displaying also a minimal loss in terms of $R^{2}$ (which confirms the doubtful importance of branch structural order). Moreover, although the model with two explanatory variables was slightly better with respect to the one with only one fixed effect $(p=0.03)$, the residual variance and the AICc were similar and the gain in terms of $R^{2}$ was also minimal (Table 4). We, therefore, retained the most parsimonious model with the branch height as only fixed effect as the more robust and suitable for validation. 


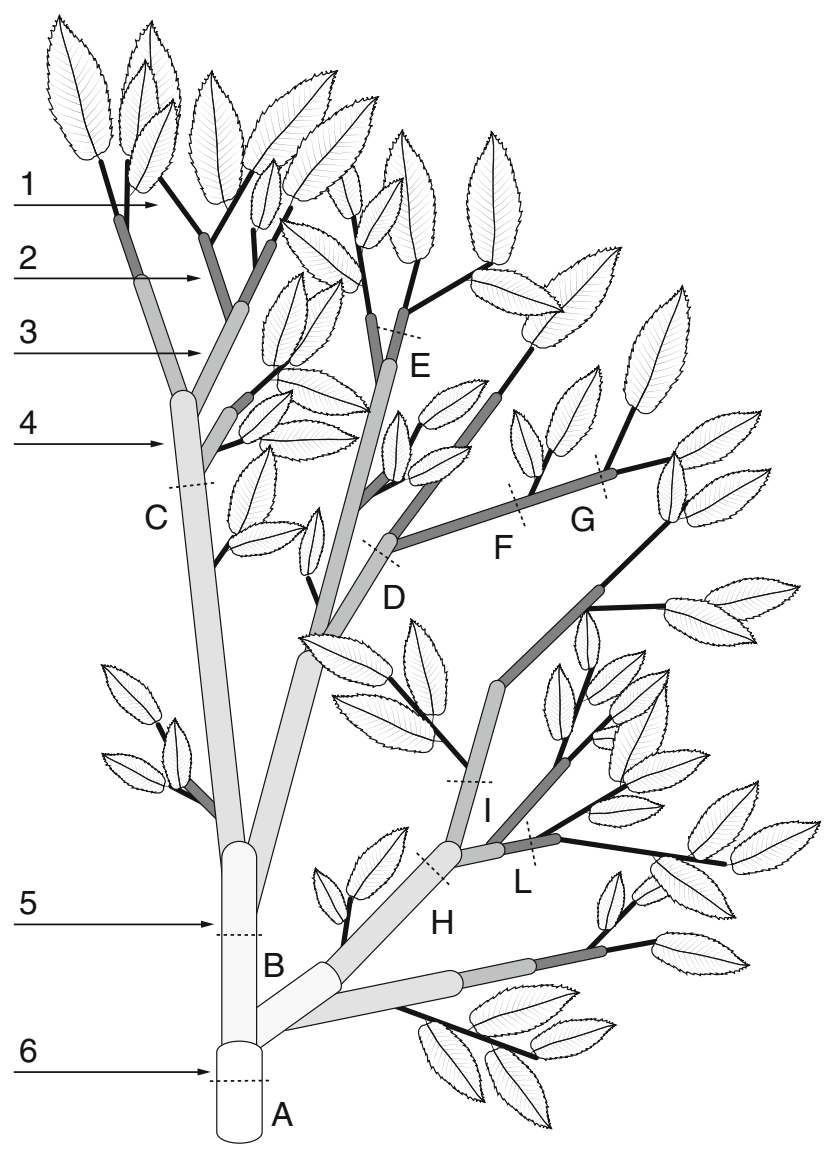

Fig. 3 Schematical representation and coding system of a branch. Letters represent ten sapwood sections. $\mathbf{a}$ is the parent section of $\mathbf{b}$ and $\mathbf{h}$. $\mathbf{b}$ is the parent section of $\mathbf{c}-\mathbf{e}$ and so on. Leaf area $\left(A_{L}\right)$ associated with section $\mathbf{a}$ is the sum of the $A_{L}$ of all the sections $(\mathbf{a}-\mathbf{l}) . A_{L}$ of section $\mathbf{b}$ is the sum of the $A_{L}$ of sections $\mathbf{b}-\mathbf{g}$, etc. Numbers represent the structural order of the branch based on the Strahler system (see Borchert and Slade 1981). The terminal shoot is labeled with the number 1 . Going centripetally from the terminal shoot, the number increases by 1 when two branches of the same order (circa same diameter) meet. The pathway having the highest score is considered. In the represented case, the structural order is 6 . Branch sections are colored according to their age (e.g., section e corresponds to a 1 year old branch and section a corresponds to a 5 years old branch)

In such a simplified model, the value of the intercept (0.8243, Eq. 1) theoretically represents the mean $A_{L}: A_{S}$ ratio of the branches when the branch height effect is removed:

$$
\begin{aligned}
\mathrm{A}_{\mathrm{L}}: \mathrm{A}_{\mathrm{S}}= & 0.8243-0.0282 \times \text { height }_{\text {branch }} \\
& +N(0, d) \text { site }_{\text {id }} / \text { tree }_{\text {id }}
\end{aligned}
$$

From this equation, we can deduce that for two branches of the same tree placed at heights differing by $10 \mathrm{~m}$, we can expect a difference of $0.282 \mathrm{U}$ in the $\mathrm{A}_{\mathrm{L}}: \mathrm{A}_{\mathrm{S}}$ ratio. The biological meaning of the intercept $(0.8243)$ corresponds to the $A_{L}: A_{S}$ ratio of a hypothetical average chestnut branch at the ground level.
Solving the Eq. 1 for the intercept term with its variation in the population of branches among sites and trees, we obtain Eq. 2:

$$
\begin{aligned}
& 0.8243+N(0, d) \text { site }_{\text {id }} / \text { tree }_{\text {id }} \\
& \quad=\mathrm{A}_{\mathrm{L}}: \mathrm{A}_{\mathrm{S}}+0.0282 \times \text { height }_{\text {branch }}
\end{aligned}
$$

Given a measured $A_{L}: A_{S}$ value of a branch at a given height of a specific tree, we can assume that the equation for obtaining the theoretical ground level $A_{L}: A_{S}$ ratio $\left(A_{L}: A_{S g r o u n d}\right)$ for this tree is as follows:

$\mathrm{A}_{\mathrm{L}}: \mathrm{A}_{\mathrm{Sground}}=\mathrm{A}_{\mathrm{L}}: \mathrm{A}_{\text {Smeasured }}+0.0282 \times$ height $_{\text {branch }}$

Compared to the measured $A_{L}: A_{S}$, the so calculated $A_{L}: A_{\text {Sground }}$ minimizes the intra-tree differences in the $\mathrm{A}_{\mathrm{L}}: \mathrm{A}_{\mathrm{S}}$ ratio as confirmed by the ANOVA on the validation dataset (the $A_{L}: A_{S}$ ratio did not differ among the 32 trees (F $31,33=1.03, P=0.5$ ), while $\mathrm{A}_{\mathrm{L}}: \mathrm{A}_{\mathrm{Sground}} \operatorname{did}(\mathrm{F} 31$, $33=7, P<0.001)$ ).

Moreover if we consider the ratio between the intra-tree $A_{L}: A_{S}$ of the validation dataset (smaller value divided by the greater), we obtain a significant approach to the identity value of 1 for the $A_{L}: A_{S g r o u n d}$ when compared to the originally measured $A_{L}: A_{S}$ (Fig. 8, non-parametric MannWhitney $U$ test with $p<0.001$ ).

\section{Discussion}

Branch level and type

Pipe model rules such as the allometric relationships between $A_{L}$ and $A_{S}$ were observed in Castanea sativa, especially at the intra-branch level. Our results are consistent with studies on other tree species (e.g., Rogers and Hinckley 1979; Kaufmann and Troendle 1981; Mencuccini and Grace 1994) suggesting that a physiological balance exists between the considered parameters (Shinozaki et al. 1964a, b; Cruiziat et al. 2002).

When considering the single branch sections with respect to the whole branch, the $A_{L}: A_{S}$ variation slightly increases from the largest section toward the branch tips. This (positive and negative) variability among small branches (with diameters smaller than $7 \mathrm{~mm}$ ) may be due to local foliage damage (which mainly causes local effects; e.g., Ruohomäki et al. 1997) and to the presence of a different shoot type (usually shoots with many female and male flowers tend to have fewer leaves than those without).

Epicormic branches display a higher $A_{L}: A_{S}$ than structural crown branches. A number of studies already highlighted the greater vigor of epicormic branches (e.g., Ito et al. 1995; Otoda and Ishii 2008), showing that plants are able to unequally redistribute the internal water flow 


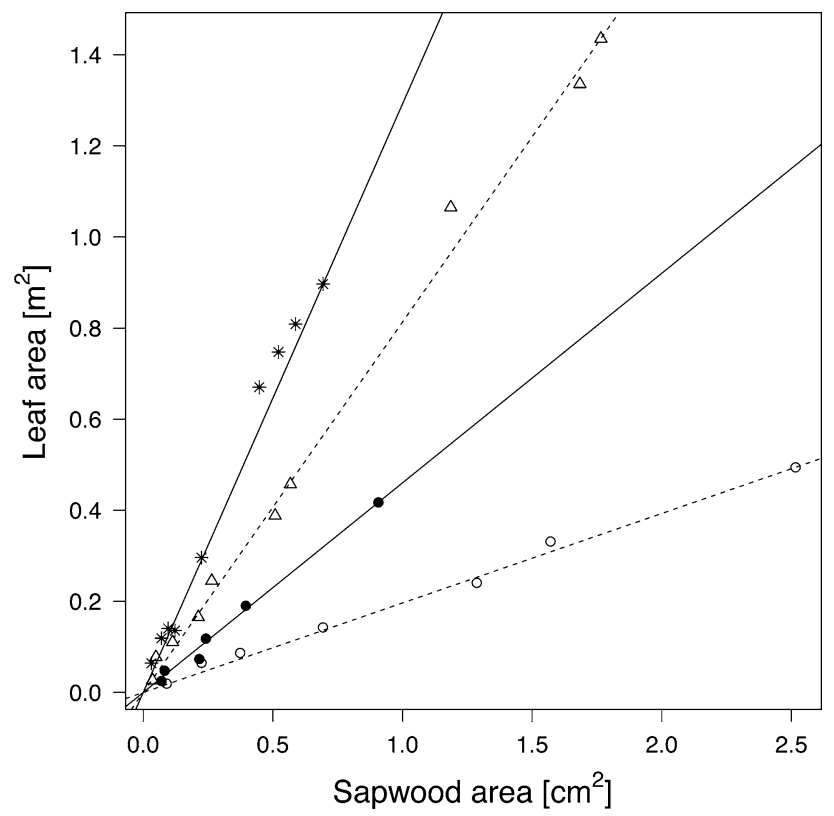

Fig. $4 A_{L}: A_{S}$ at the branch level: example of four selected branches. Lines represent the $A_{L}: A_{S}$ of the whole branch (highest sapwood area value) with a null intercept

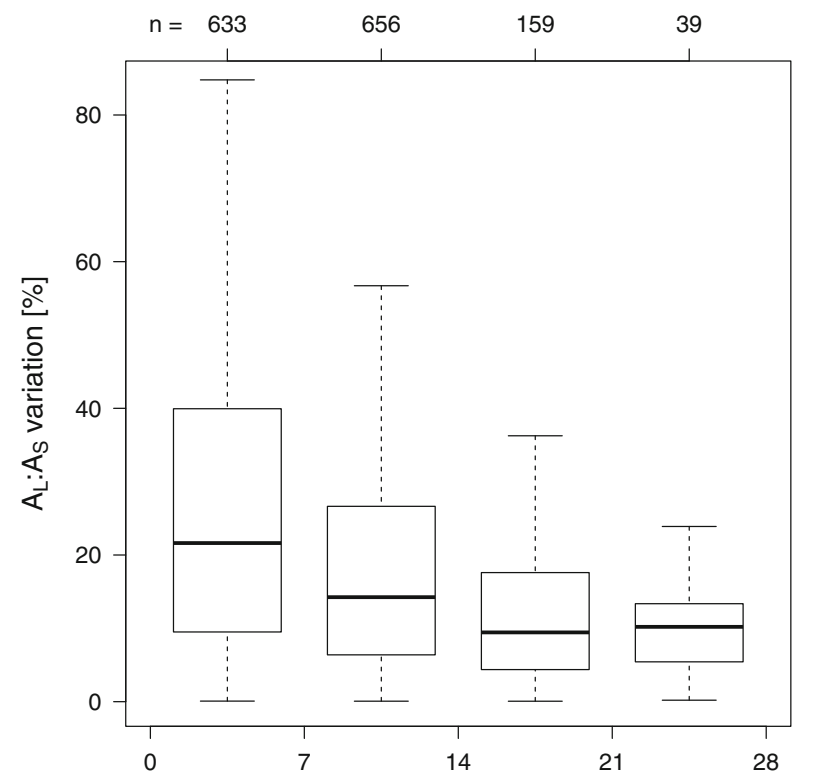

Maximum diameter of the considered branch section [mm]

Fig. 5 Variation in $A_{L}: A_{S}$ ratio between the single branch sections and the whole branch based on the diameter of the considered branch section. Labels on the top ( $n$ ) represent the number of sampled sections. Outliers are not shown

(Zimmermann 1978, 1983). Ishii et al. (2007) suggested that epicormic branches are able to maintain higher hydraulic conductivity countering the general trend of an increased reduction due to the number of annual nodes and

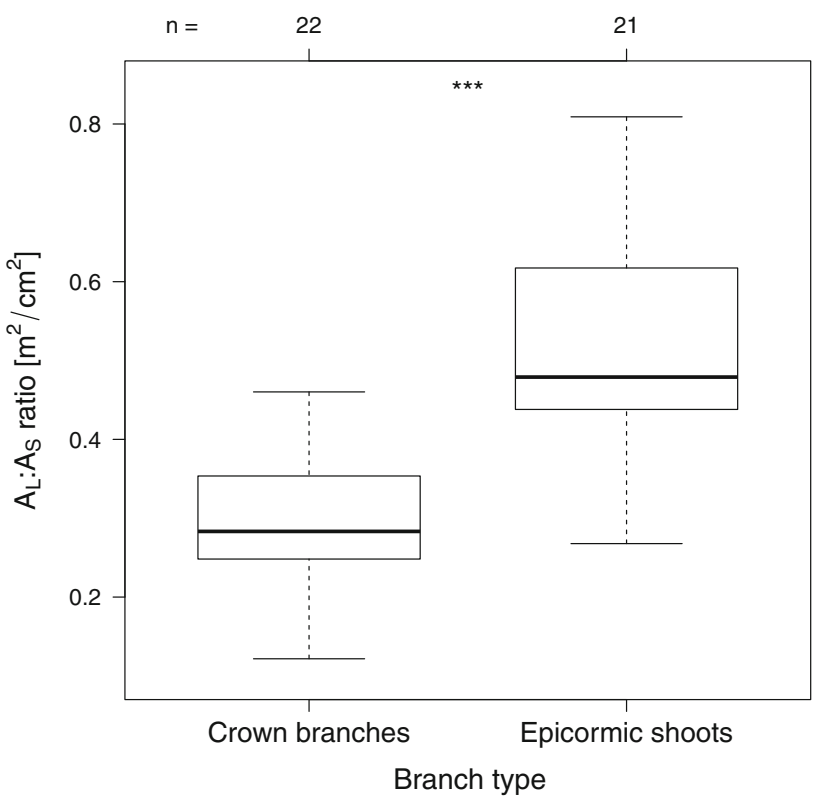

Fig. 6 Differences in $A_{L}: A_{S}$ ratio between crown and epicormic branches, among branches not higher than $10 \mathrm{~m}$ from trees growing in similar conditions. Labels on the top $(n)$ represent the number of sampled branches in each category. $p<0.001$, non-parametric Mann-Whitney $U$ test

junctions (Larson and Isebrands 1978; Rust and Huttl 1999) and a longer distance from the trunk (Ewers and Zimmermann 1984a, b). Epicormic branches alter the hydraulic architecture, connecting directly to an axis of lower order and higher hydraulic conductivity, such as the main trunk (Tyree and Ewers 1991; Kozlowski and Pallardy 1996), and shortening the water path length to the new foliage correspondingly (Rust and Huttl 1999; Ishii et al. 2002, 2007; Otoda and Ishii 2008). From an ecological point of view, such resprouting ability enhances the possibility for young woody plants to survive in disturbed habitats (Del Tredici 2001), while in mature trees, the reiterative ability allows the individual to restore its original architecture (Begin and Filion 1999), to maintain the leaf area in the inner crown (Nicolini et al. 2001; Ishii et al. 2007) and to quickly respond to disturbances (Ito et al. 1999), which results in an increased probability of longevity (Gerrish 1990; Ishii et al. 2007). Our results thus basically confirm the different physiological characteristics of the epicormic branches in terms of both water supply and growth performance. When referring specifically to the chestnut tree, this may explain the millenary interest of humans for cultivating the tree species through regular coppicing and as well as regularly pruned orchard trees for fruit production (Conedera and Krebs 2008). This is also depicted in the longevity of chestnut trees regularly submitted to rejuvenation through cultural inputs such as crown pruning (Krebs et al. 2012). 
Table $3 \mathrm{Al} /$ As ratio variability within trees

\begin{tabular}{lllllrrr}
\hline & Model terms & LogLik & $s_{\text {resid }}^{2}$ & $s_{\text {resid }}$ & AIC $_{\mathrm{c}}$ & $\bar{R}_{\text {Cox }}^{2}$ & $\bar{R}_{\text {Xu }}^{2}$ \\
\hline 1 & $\beta_{0}+\beta_{1} H+\beta_{2} \mathrm{SO}+\beta_{3} \mathrm{BO}+N(0$, & 91.57 & 0.00670 & 0.08184 & -167.81 & 0.647 & 0.671 \\
& $d)$ & & & & & \\
2 & $\beta_{0}+\beta_{1} H+\beta_{3} \mathrm{BO}+N(0, d)$ & 90.01 & 0.00701 & 0.08373 & -167.05 & 0.635 \\
3 & $\beta_{0}+\beta_{1} H+N(0, d)$ & 87.53 & 0.00708 & 0.08416 & -164.37 & 0.615 & 0.652 \\
4 & $\beta_{0}+N(0, d)$ & 43.12 & 0.02036 & 0.14269 & -77.78 & 0.000 & 0.000 \\
\hline
\end{tabular}

Best linear mixed models with ML estimation according to the AICc ranking

1 best model, 2 best model with only 2 fixed effects, 3 best model with only 1 fixed effect, 4 null model with intercept only $H$ branch height at cutting point, $S O$ branch structural order, $B O$ branch orientation, $\beta_{0} \ldots$ z fixed effects, $N(0, d)$ random terms

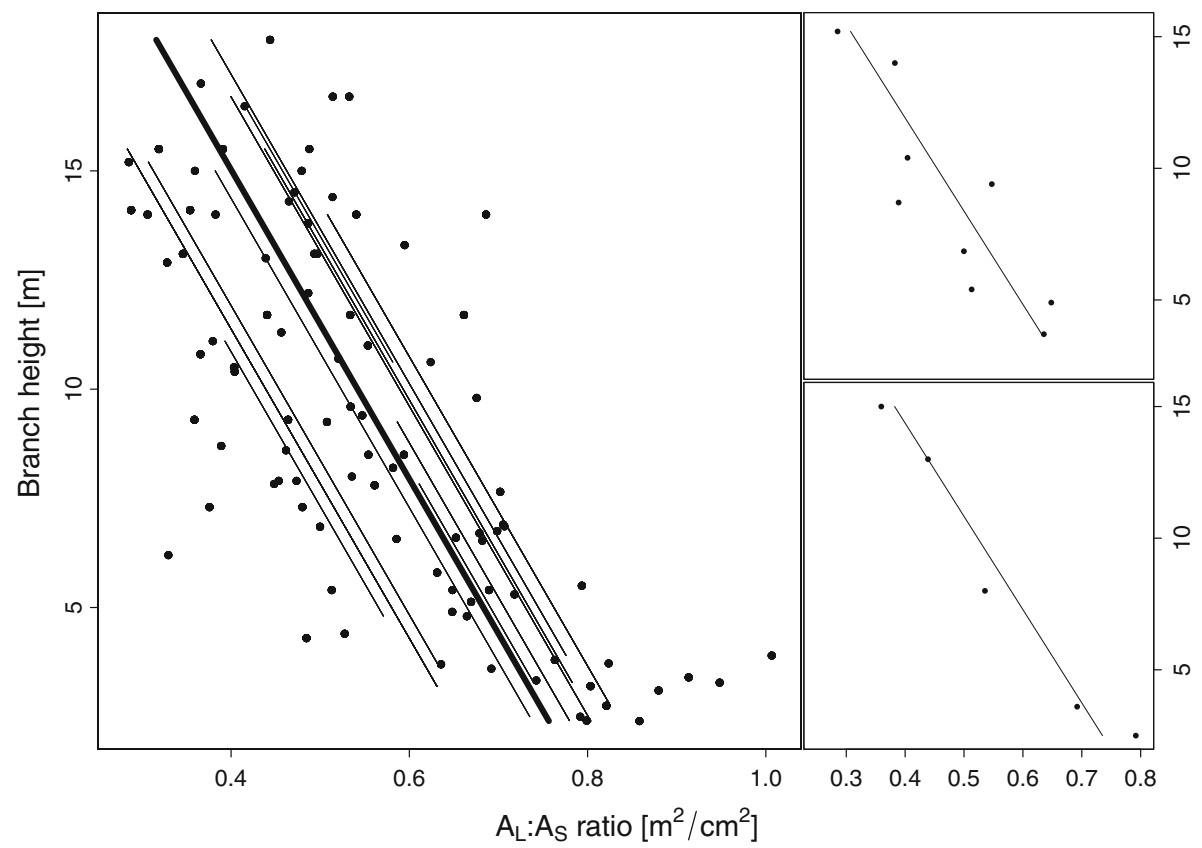

Fig. 7 Fitted values obtained by the most parsimonious mixed model considering the whole training dataset (left plot; $n=93$ ) or for selected trees (small plots on the right). Black dots represent the branches. The bold line (specified by $0.8243-0.0282 \times$ height $_{\text {branch }}$ )

Tree level

Studies regarding other tree species have already reported a declining $A_{L}$ : $A_{S}$ ratio with tree height (e.g., McDowell et al. 2002; Sellin and Kupper 2006). Different hypotheses have been formulated in this regard as, for example, being a way for trees to support increasing hydraulic constrictions with tree height (Becker et al. 2000; McDowell et al. 2002) and the related decreasing conductivity of the xylem tissue (Tyree and Ewers 1991; Mencuccini 2003). Increasing sapwood area with respect to leaf area should thus be a homeostatic way not only of coping with increasing hydraulic constraints along the tree, but of maintaining canopy conductance (Becker et al. 2000). Although some experiments pointed out that reduction in the $A_{L}: A_{S}$ ratio could fully mitigate hydraulic limitations (e.g., Barnard and represents the fitted values for the population model and thin lines the within-site/tree fitted values (obtained by $0.8243-0.0282 \times$ height $_{\text {branch }}+N(0, d)$ site $_{\text {id }} /$ tree $\left._{\text {id }}\right)$

Ryan 2003), this hypothesis is still controversial. A number of studies suggest that this compensatory shift in the $A_{L}: A_{S}$ ratio only partially alleviates the problem (Ryan et al. 2000; McDowell et al. 2002; Novick et al. 2009), stating that other mechanisms like changes in tree water storage with height (Phillips et al. 2003b) or increased hydraulic redistributed water (Brooks et al. 2002) contribute significantly to the water balance of a tree.

This reduction of $A_{L}: A_{S}$ ratio with height could also relate to abiotic stress. Suggested by Waring and Schlesinger (1985) and then confirmed by a study on Populus euramericana (Dode) Guinier and Fagus sylvatica L., larger surface of sapwood area for a given leaf area is necessary in sites exposed to environmental stress compared to protected sites (Mazzoleni 1990). Similarly, light- and wind-exposed branches from the crown top are subjected to 
Table 4 REML estimates and mean estimates across MCMC samples of the fixed effects

\begin{tabular}{|c|c|c|c|c|c|c|c|}
\hline Model & Fixed effect & Estimate & MCMC mean & HPD95 & HPD95 $5_{\text {upper }}$ & pMCMC & $\operatorname{Pr}(>|t|)$ \\
\hline A & Intercept & 0.8213 & 0.8112 & 0.6826 & 0.9325 & 0.0001 & 0.0000 \\
\hline A & Branch height $(\mathrm{H})$ & -0.0276 & -0.0273 & -0.0318 & -0.0226 & 0.0001 & 0.0000 \\
\hline $\mathrm{A}$ & Structural order (SO) & -0.0177 & -0.0182 & -0.0376 & 0.0022 & 0.0758 & 0.0775 \\
\hline $\mathrm{A}$ & Branch orientation (BO) & 0.0509 & 0.0583 & 0.0154 & 0.1031 & 0.0110 & 0.0244 \\
\hline B & Intercept & 0.7444 & 0.7371 & 0.6485 & 0.8324 & 0.0001 & 0.0000 \\
\hline $\mathrm{B}$ & Branch height $(\mathrm{H})$ & -0.0280 & -0.0278 & -0.0326 & -0.0234 & 0.0001 & 0.0000 \\
\hline $\mathrm{B}$ & Branch orientation (BO) & 0.0522 & 0.0565 & 0.0139 & 0.1006 & 0.0150 & 0.0173 \\
\hline $\mathrm{C}$ & Intercept & 0.82430 & 0.8212 & 0.7538 & 0.8929 & 0.0001 & 0.0000 \\
\hline $\mathrm{C}$ & Branch height $(\mathrm{H})$ & -0.0282 & -0.0279 & -0.0326 & -0.0234 & 0.0001 & 0.0000 \\
\hline
\end{tabular}

HPD95 $5_{\text {lower/upper }}$ are the highest posterior density intervals and the last two columns show $p$ values calculated with the posterior distribution (pMCMC) and the $t$ distribution $(\operatorname{Pr}(>|\mathrm{t}|))$

$A$ Best model of variability of Al/As within trees, $B$ most parsimonious model with 2 fixed effects only, $C$ most parsimonious model with a single fixed effect only

more water stress with respect to shaded branches at the crown bottom (higher evapotranspirative demand).

The negative relationship between the $A_{L}: A_{S}$ ratio and the branch structural order found in our study had a doubtful importance and seems to be marginal compared to height. Moreover, it appears to have no real effect in this context and we thus did not investigate further.

Finally, the fact that also the branch orientation was retained in the best AICc model (positively related to $A_{L}: A_{S}$ ratio, meaning that branches with a value of around 0 (southwest facing) are more exposed to the sun with respect to those approaching a value of 2 (northeast facing)) is in concordance with the hypothesis of a trend toward lower $\mathrm{A}_{\mathrm{L}}: \mathrm{A}_{\mathrm{S}}$ ratio in case of increasing evapotranspirative demand.

\section{Conclusions}

In this study, we confirmed the existence of an allometric relationship within the European chestnut tree in terms of $A_{L}: A_{S}$ ratio, especially at intra-branch level. At tree level, the main parameter influencing the $A_{L}: A_{S}$ ratio is the height of the branch, which is a good indicator of the hydraulic constraints due to stem height and the evapotranspirative demand due to wind and sun exposure. For environmental studies, it is very important to carefully avoid epicormic branches and select a homogeneous set of structural crown branches (e.g., with a constant branch height and a minimum diameter of $10 \mathrm{~mm})$.

We furthermore propose the notion of the $A_{L}: A_{S}$ ratio of a theoretical branch at ground level $\left(\mathrm{A}_{\mathrm{L}}: \mathrm{A}_{\mathrm{Sground}}\right)$ as a modeling approach to partially mitigate differences due to sampling height or to enable direct comparison of the

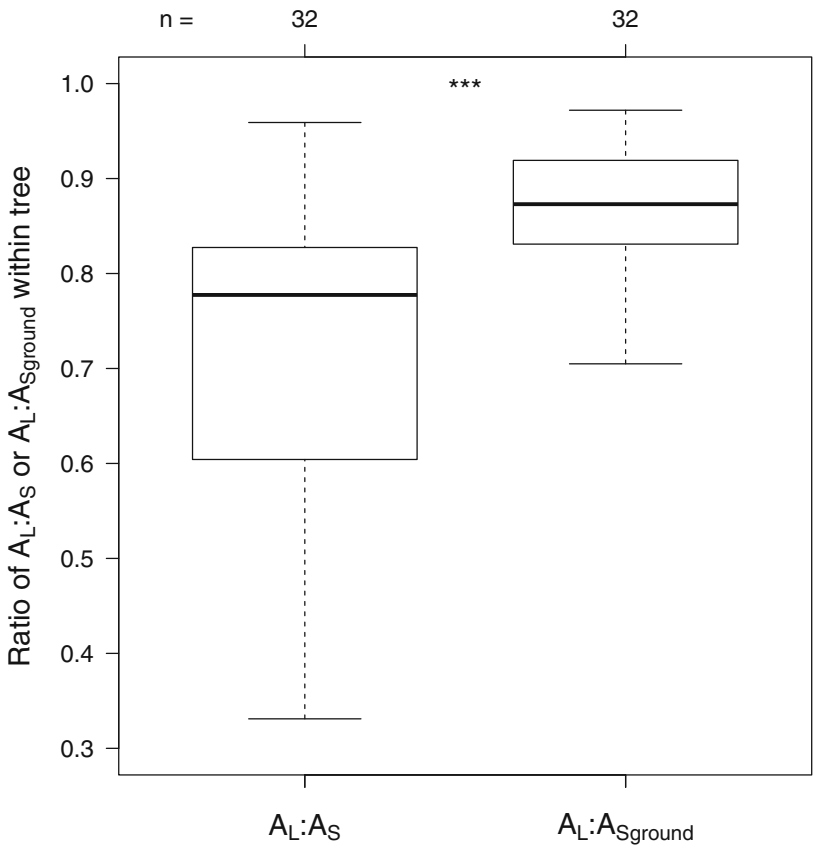

Fig. 8 Box plots of the ratios between pairs of branches within trees of the validation dataset (lower branch value to higher branch value), based on $A_{L}: A_{S}$ and $A_{L}: A_{\text {Sground. }}$. The more the branches have similar $A_{L}: A_{S}$ ratios, the more the ratios are closer to the identity value of 1 . Labels on the top $(n)$ represent the number of trees. Outliers are not shown. $p<0.001$, non-parametric Mann-Whitney $U$ test

$A_{L}: A_{S}$ ratio of trees growing in different sites or environmental conditions.

Author contribution statement EG: sampling design, fieldwork, data analysis, drawings, manuscript draft, and submission. GBP: concept of the study, sampling design, database development and management, data analysis, and manuscript revision. PK: leaf area measurement concept and data management. SM: concept of the study, sampling design, and manuscript revision. MC: research 
project coordination, sampling design, manuscript editing, and research funding.

Conflict of interest The authors declare that they have no conflict of interest.

\section{References}

Arber A (1928) Tree habit in angiosperms: its origin and meaning. New Phytol 27:69-84

Arber A (1950) The natural philosophy of tree form. Cambridge University, Cambridge

Aussenac G, Granier A (1988) Effects of thinning on water stress and growth in douglas-fir. Can J For Res 18:100-105

Barnard HR, Ryan MG (2003) A test of the hydraulic limitation hypothesis in fast-growing Eucalyptus salign. Plant Cell Environ 26:1235-1245

Bartelink H (1997) Allometric relationships for biomass and leaf area of beech (Fagus sylvatica). Ann Sci For 54:12

Becker P, Meinzer FC, Wullschleger SD (2000) Hydraulic limitation of tree height: a critique. Funct Ecol 14:4-11

Beers TW, Dress PE, Wensel LC (1966) Aspect transformation in site productivity research. J For 64:691-692

Berthier S, Kokutse AD, Stokes A, Fourcaud T (2001) Irregular heartwood formation in Maritime pine (Pinus pinaster Ait.): consequences for biomechanical and hydraulic tree functioning. Ann Bot 87:19-25

Bleby TM, Colquhoun IJ, Adams MA (2012) Hydraulic traits and water use of Eucalyptus on restored versus natural sites in a seasonally dry forest in southswestern Australia. For Ecol Manag 274:58-66

Borchert R, Slade NA (1981) Bifurcation ratios and the adaptive geometry of trees. Bot Gaz 142:394-401

Brix H, Mitchell AK (1983) Thinning and nitrogen fertilization effects on sapwood development and relationships of foliage quantity to sapwood area and basal area in Douglas-fir. Can J For Res 13:384-389

Brooks RJ, Meinzer CF, Coulombe R, Gregg J (2002) Hydraulic redistribution of soil water during summer drought in two contrasting Pacific Northwest coniferous forests. Tree Physiol 22:1107-1117

Chiba Y (1990) Plant form analysis based on the pipe model theory. I. A statical model within the crown. Ecol Res 5:207-220

Chiba Y (1991) Plant form analysis based on the pipe model theory. II. Quantitative analysis of ramification in morphology. Ecol Res 6:21-28

Chiba Y (1998) Architectural analysis of relationship between biomass and basal area based on pipe model theory. Ecol Model 108:219-225

Conedera M, Krebs P (2008) History, present situation and perspective of chestnut cultivation in Europe. In: Abreu CG, Peixoto FP, Gomes-Laranjo J (eds): Proceedings of the second Iberian chestnut congress, Vila Real (P). Acta Hort. 784:23-27

Cruiziat P, Cochard H, Ameglio T (2002) Hydraulic architecture of trees: main concepts and results. An For Sci 59:723-752

Dean TJ, Long JN (1986) Variation in sapwood area-leaf area relations within two stands of lodgepole pine. For Sci 32:749-758

Del Tredici P (2001) Sprouting in temperate trees: a morphological and ecological review. Bot Rev 67:121-140

Delzon S, Sartore M, Burlett R, Dewar R, Loustau D (2004) Hydraulic responses to height growth in maritime pine trees. Plant Cell Environ 27:1077-1087

Ewers FW, Zimmermann MH (1984a) The hydraulic architecture of balsam fir (Abies balsamea). Physiol Plant 60:453-458

Ewers FW, Zimmermann MH (1984b) The hydraulic architecture of eastern henlock (Tsuga canadensis). Can J Bot 62:940-946
Gerrish G (1990) Relating carbon allocation patterns to tree senescence in Metrosideros forests. Ecol 71:1176-1184

Gotsch SG, Geiger EL, Franco AC, Goldstein G, Meinzer FC, Hoffmann WA (2010) Allocation to leaf area and sapwood area affects water relations of co-occurring savanna and forest trees. Oecol 163:291-301

Gould PJ, Harrington CA (2008) Extending sapwood : leaf area relationships from stems to roots in coast douglas-fir. Ann For Sci 65:8

Hallé F, Oldeman RAA (1970) Essai sur l'architecture et la dynamique de croissance des arbres tropicaux. Masson, Paris

Hallé F, Oldeman RAA, Tomlinson PB (1978) Tropical trees and forests: an architectural analysis. Springer, Berling

Hasegawa S, Koba K, Tayasu I (2003) Carbon autonomy of reproductive shoots of siberian alder (Alnus hirsuta var. sibirica). J Plant Res 116:183-188

Huber B (1928) Weitere quantitative untersuchungen über das wasserleitungssystem der pflanzen. Jahrb Wiss Bot 67:877-959

Infante JM, Mauchamp A, Fernández-Alé R, Joffre R, Rambal S (2001) Within-tree variation in transpiration in isolated evergreen oak trees: evidence in support of the pipe model theory. Tree Physiol 21:409-414

Ishii HT, Ford ED, Dinnie CE (2002) The role of epicormic shoot production in maintaining foliage in old Pseudotsuga menziesii (douglas-fir) trees II. Basal reiteration from older branch axes. Can J Bot 80:916-926

Ishii HT, Ford ED, Kennedy MC (2007) Physiological and ecological implications of adaptive reiteration as a mechanism for crown maintenance and longevity. Tree Physiol 27:455-462

Ito S, Sakuta K, Gyokusen K (1995) Distribution of hydraulic resistance in seedlings, sprouts and an adult tree of Pasania edulis Makino. Ecol Res 10:143-149

Ito K, Ito S, Gyokusen K, Saito A (1999) Ecological roles of stem sprouts and creeping sprouts of Aucuba japonica thunb. J For Res 4:137-143

Kaufmann MR, Troendle CA (1981) The relationship of leaf area and foliage biomass to sapwood conducting area in four subalpine forest tree species. For Sci 27:477-482

Kozlowski TT, Pallardy SG (1996) Physiology of woody plants. Academic, San Diego

Krebs P, Koutsias N, Conedera M (2012) Modelling the eco-cultural niche of giant chestnut trees: new insights into land use history in southern Switzerland through distribution analysis of a living heritage. J Hist Geogr 38:372-386

Larson PR, Isebrands JG (1978) Functional significance of nodal constricted zone in Populus deltoides. Can J Bot 56:801-804

Magnani F, Mencuccini M, Grace J (2000) Age-related decline in stand productivity: the role of structural acclimation under hydraulic constraints. Plant Cell Environ 23:251-263

Mäkelä A (1986) Implications of the pipe model theory on dry matter partitioning and height growth in trees. J Theor Biol 123:103-120

Martin-Stpaul NK, Limousin JM, Vogt-Schilb H, Rodriguez-Calcerrada J, Rambal S, Longepierre D, Misson L (2013) The temporal response to drought in a Mediterranean evergreen tree: comparing a regional precipitation gradient and a throughfall exclusion experiment. Glob Chang Biol 19:2413-2426

Mazzoleni S (1990) Relazioni tra aree fogliari e superfici di conduzione nel fusto nell'analisi di gradienti ambientali. Linea Ecol pp 27-30

Mazzoleni S, Schirone B (1990) Allometric estimations of woody and foliar biomass. Applications on Quercus cerris sprouts and mediterranean shrubs. Annali Botanica XVIII

McDowell N, Barnard H, Bond B, Hinckley T, Hubbard R, Ishii H, Köstner B, Magnani F, Marshall J, Meinzer F, Phillips N, Ryan M, Whitehead D (2002) The relationship between tree height and leaf area: sapwood area ratio. Oecol 132:12-20 
Mencuccini M (2003) The ecological significance of long-distance water transport: short-term regulation, long-term acclimation and the hydraulic costs of stature across plant life forms. Plant Cell Environ 26:163-182

Mencuccini M, Grace J (1994) Climate influences the leaf area/ sapwood area ratio in scots pine. Tree Physiol 15:1-10

Mencuccini M, Grace J (1996) Developmental patterns of aboveground hydraulic conductance in a scots pine (Pinus sylvestris L.) age sequence. Plant Cell Environ 19:939-948

Miyazaki Y, Hiura T, Kato E, Funada R (2002) Allocation of resources to reproduction in Styrax obassia in a masting year. Ann Bot 89:767-772

Nagelkerke NJD (1991) A note on a general definition of the coefficient of determination. Biometrika 78:691-692

Nicolini E, Chanson B, Bonne F (2001) Stem growth and epicormic branch formation in understory beech trees (Fagus sylvatica L.). Ann Bot 87:737-750

Novick K, Oren R, Stoy P, Juang JY, Siqueira M, Katul G (2009) The relationship between reference canopy conductance and simplified hydraulic architecture. Adv Water Resour 32:809-819

Otoda T, Ishii H (2008) Basal reiteration improves the hydraulic functional status of mature cinnamomum camphora trees. Trees 23:317-323

Phillips N, Bond BJ, McDowell NG, Ryan MG, Schauer A (2003a) Leaf area compounds height-related hydraulic costs of water transport in Oregon White Oak trees. Funct Ecol 17:832-840

Phillips NG, Ryan MG, Bond BJ, McDowell NG, Hinckley TM, Cermák J (2003b) Reliance on stored water increases with tree size in three species in the pacific northwest. Tree Physiol 23:237-245

Pothier D, Margolis A (1991) Analysis of growth and light interception of balsam fir and white birch saplings following precommercial thinning. Ann Sci For 48:123-132

R Development Core Team (2011) A language and environment for statistical computing. R Foundation for statistical computing, Vienna. ISBN 3-900051-07-0

Rogers R, Hinckley TM (1979) Foliar weight and area related to current sapwood area in oak. For Sci 25:298-303

Ruohomäki K, Haukioja E, Repka S, Lehtilä K (1997) Leaf value: effects of damage to individual leaves on growth and reproduction of mountain birch shoots. Ecology 78:2105-2117

Rust S, Huttl RF (1999) The effect of shoot architecture on hydraulic conductance in beech (Fagus sylvatica L.). Trees-Struct Funct 14:39-42

Ryan MG, Bond BJ, Law BE, Hubbard RM, Woodruff D, Cienciala E, Kucera J (2000) Transpiration and whole-tree conductance in ponderosa pine trees of different heights. Oecol 124:553-560
Sellin A, Kupper P (2006) Spatial variation in sapwood area to leaf area ratio and specific leaf area within a crown of silver birch. Trees 20:311-319

Shinozaki K, Yoda K, Hozumi K, Kira T (1964a) A quantitative analysis of plant form - the pipe model theory I. Basic analyses. Jpn J Ecol 14:97-105

Shinozaki K, Yoda K, Hozumi K, Kira T (1964b) A quantitative analysis of plant form-the pipe model theory II. Further evidence of the theory and its application in forest ecology. Jpn J Ecol 14:133-139

Snell JA, Brown JK (1978) Comparison of tree biomass EstimatorsDBH and sapwood area. For Sci 24:455-457

Sone K, Suzuki AA, Miyazawa SI, Noguchi K, Terashima I (2009) Maintenance mechanisms of the pipe model relationship and leonardo da vinci-s rule in the branching architecture of Acer rufinerve trees. J Plant Res 122:41-52

Sprugel DG, Hinckley TM, Schaap W (1991) The theory and practice of branch autonomy. Ann Rev Ecol Syst 22:309-334

Tinner W, Hubschmid P, Wehrli M, Ammann B, Conedera M (1999) Long-term forest fire ecology and dynamics in southern Switzerland. J Ecol 87:273-289

Tyree MT, Ewers FW (1991) Tansley review no. 34. The hydraulic architecture of trees and other woody plants. New Phytol 119:345-360

Waring RH, Schlesinger WH (1985) Forest ecosystems: concepts and management. Academic, New York

White D, Beadle C, Worledge D, Honeysett J, Cherry M (1998) The influence of drought on the relationship between leaf and conducting sapwood area in Eucalyptus globulus and Eucalyptus nitens. Trees-Struct Funct 12:406-414

Wright IJ, Falster DS, Pickup M, Westoby M (2006) Cross-species patterns in the coordination between leaf and stem traits, and their implications for plant hydraulics. Physiol Plant 127:445-456

$\mathrm{Xu}$ R (2003) Measuring explained variation in linear mixed effects models. Statist Med 22:3527-3541

Yamamoto K, Kobayashi S (1993) Analysis of crown structure based on the pipe model theory. J Jpn For Soc 75:445-448

Zimmermann MH (1978) Hydraulic architecture of some diffuseporous trees. Can J Bot 56:2286-2295

Zimmermann MH (1983) Xylem structure and the ascent of sap. Springer, Germany

Zuur AF, Ieno EN, Walker N, Saveliev AA, Smith GM (2009) Mixed effects models and extensions in ecology with R. Statistics for biology and health. Springer, New York 